\title{
PERKEMBANGAN ENZIM PENCERNAAN LARVA IKAN PATIN, Pangasius hypophthalmus
}

\section{Development of Digestive Enzyme of Patin Pangasius hypohthalmus Larvae}

\author{
I. Effendi, D. Augustine dan Widanarni \\ Departemen Budidaya Perairan, Fakultas Perikanan dan Ilmu Kelautan, \\ Institut Pertanian Bogor, Kampus Darmaga, Bogor 16680
}

\begin{abstract}
Culture of patin Pangasius hypophthalmus especially larval rearing very depends on the supply of natural food as energy source. Artemia is the main natural food for fish larvae as a starter food, but its price is high. To reduce production cost, farmers tend to reduce the feeding frequency and shorten the Artemia feeding period. Altering feeding regime however may reduce fry quality. This relate to the availability of digestive enzymes. The objective of this study was to examine digestive enzymes activity in patin larvae fed with different feeding regime. By shorten feeding period with Artemia to 2-4 days and Tubifex,substitution, the enzymes activity of protease, lipase and amylase were revealed similar pattern The enzymes activity tends to increase and reach the peak at day 7 , and decrease later on until day 15 after hatching. Survival rate of fish were varied for each treatment, and the highest survival rate was obtained when larvae were fed by Artemia for 8 days. Blood worm were not fully digested by patin larvae at early stage.
\end{abstract}

Keywords: enzyme, digestion, patin, Pangasius hypophthalmus

\begin{abstract}
ABSTRAK
Proses budidaya ikan patin, Pangasius hypophthalmus terutama pembenihan sangat tergantung oleh ketersediaan pakan alami sebagai sumber energinya. Artemia merupakan pakan alami yang banyak diberikan pada saat larva ikan mulai makan, namun harganya relatif tinggi. Untuk menekan biaya produksi, petani ikan patin cenderung mengurangi frekuensi pemberian Artemia dan mempersingkat waktu pemberiannya. Penggeseran jadwal ini diduga mengakibatkan penurunan kualitas benih ikan patin yang dihasilkan yang berhubungan dengan kesiapan enzim pencernaannya. Penelitian ini dilakukan untuk mengetahui aktivitas enzim pada larva ikan patin dengan jadwal pemberian pakan yang berbeda. Dengan memotong waktu pemberian Artemia 2 - 4 hari dan disubstitusi dengan Tubifex, aktifitas enzim protease, lipase dan amilase pada larva ikan patin, memiliki pola yang sama. Aktifitas enzim cenderung meningkat dan mencapai puncak pada umur 7 hari, selanjutnya terus menurun sampai larva berumur 15 hari. Kelangsungan hidup ikan selama penelitian berbeda-beda untuk setiap perlakuan dengan nilai tertinggi dicapai oleh larva yang diberi pakan Artemia sampai berumur 8 hari. Larva ikan patin belum siap sepenuhnya untuk menerima pakan berupa cacing sutera sejak stadia awalnya.
\end{abstract}

Kata kunci: Enzim, Pencernaan, Patin, Pangasius hypophthalmus

\section{PENDAHULUAN}

Ikan patin, Pangasius hypophthalmus merupakan ikan konsumsi yang juga menjadi komoditas hias. Sebagai ikan konsumsi, keistimewaan ikan patin antara lain rasanya yang khas, rendah kalori serta struktur dagingnya yang kenyal tetapi empuk (Hernowo, 2001).

Dalam proses budidaya ikan terutama pembenihan sangat tergantung oleh ketersediaan pakan alami sebagai sumber energinya. Artemia merupakan pakan alami yang banyak diberikan pada saat larva ikan mulai makan. Namun dengan harganya yang relatif tinggi akan mempengaruhi besarnya biaya produksi secara keseluruhan. Untuk menekan besarnya biaya produksi, petani pembenih ikan patin cenderung mengurangi frekuensi pemberian Artemia dengan cara menggeser jadwal pemberian pakan dan mempersingkat waktu pemberiannya. Pada 
beberapa panti benih, pemberian cacing bahkan sudah dimulai sejak larva baru berumur 3 hari.

Penggeseran jadwal ini diduga mengakibatkan penurunan kualitas benih ikan patin yang dihasilkan. Hal ini dapat disebabkan oleh belum siapnya enzim pencernaan larva untuk menerima dan mencerna cacing yang diberikan. Stroband \& Dabrowski (1979) dan Buddington (1985) menyatakan bahwa pada kondisi saluran pencernaan yang masih sangat sederhana, produksi enzim-enzim pencernaanpun sangat rendah. Rendahnya aktifitas enzim dan ketiadaan salah satu atau beberapa enzim pencernaan akan sangat mempengaruhi kemampuan cerna larva.

\section{BAHAN DAN METODE}

\section{Tahap persiapan}

Wadah yang digunakan untuk
pemeliharaan larva adalah akuarium
berukuran $60 \times 50 \times 40 \mathrm{~cm}$ yang diisi air
sampai setinggi $25 \mathrm{~cm}$. Suhu air
dipertahankan pada tingkat $29-30{ }^{\circ} \mathrm{C}$ dengan
dengan karakteristik oksigen terlarut 0,89
ppm, pH 7,16 , alkalinitas $21,02 \mathrm{ppm}$ dan
amoniak 0,078 ppm. Penebaran larva
dilakukan $3-5$ hari setelah pengisian air
tersebut.

\section{Penebaran larva}

Larva ikan patin, Pangasius hypophthalmus yang ditebar berumur satu hari dengan ukuran $3,77-3,97 \mathrm{~mm}$ dan bobot $0,79 \mathrm{mg}$. Secara fisik, tubuh larva tersebut masih terlihat transparan dengan kuning telur terlihat jelas dan masih bergerak vertikal. Penebaran larva dilakukan dengan kepadatan 20 ekor/l. Proses aklimatisasi dilakukan sebelum proses penebaran yaitu dengan cara mengapungkan kantong plastik berisi larva selama 1 jam kemudian dibuka, dimasukkan air akuarium sedikit demi sedikit dan larva dilepaskan secara perlahan.

\section{Pemberian pakan}

Selama pemeliharaan larva diberi pakan berupa chlorella, Artemia dan cacing sutera (Tubifex). Tiga jadwal pemberian pakan diterapkan dalam pemeliharaan larva yaitu;

- Perlakuan I : Artemia diberikan pada umur $2-8$ hari dan Tubifex $7-15$ hari

- Perlakuan II : Artemia diberikan pada umur $2-6$ hari dan Tubifex $5-15$ hari

- Perlakuan III : Artemia diberikan pada umur $2-4$ hari dan Tubifex $3-15$ hari

Chlorella hasil kultur masal selama 19 hari diberikan pada larva mulai umur 1 hari sampai dengan 15 hari pemeliharaan sebanyak $30 \mathrm{ml}$ dengan kelimpahan $5,17 \times 10^{5}$ $\mathrm{sel} / \mathrm{ml}$. Artemia yang diberikan merupakan hasil penetasan cyste selama 24 - 36 jam yang dilakukan setiap 4 jam (pukul 06.00, 10.00, 14.00, 18.00 dan 02.00). Sedangkan pemberian pakan cacing sutera dilakukan setiap 6 jam (pukul 08.00, 14.00, 20.00 dan 02.00). Cacing sutera (Tubifex) yang diberikan dicuci terlebih dahulu kemudian dihaluskan sehingga berukuran $\pm 0,67 \mathrm{~mm}$.

Tabel 1. Jadwal pemberian pakan larva ikan patin, Pangasius hypophthalmus

\begin{tabular}{|c|c|c|}
\hline & & Umur larva (hari) \\
\hline Perlakuan & Chlorella & 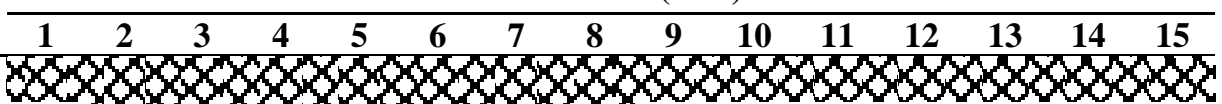 \\
\hline & $\begin{array}{l}\text { Artemia } \\
\text { Tubifex }\end{array}$ & \\
\hline II & Chlorella & 0000000000000 \\
\hline & Artemia & 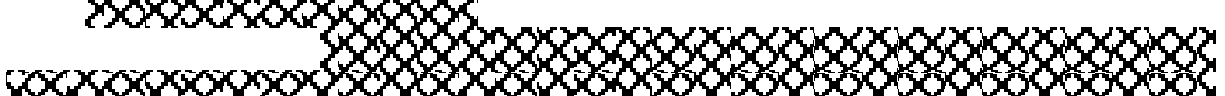 \\
\hline III & $\begin{array}{l}\text { Chlorella } \\
\text { Artemia }\end{array}$ & 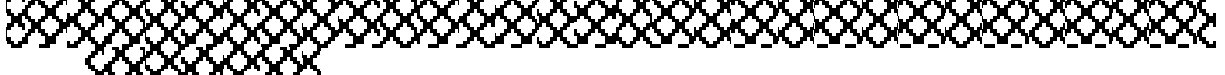 \\
\hline & Tubifex & $\times 00$ \\
\hline
\end{tabular}




\section{Pengamatan terhadap enzim pencernaan}

Pengambilan sampel larva dilakukan untuk keperluan asai enzim, pembuatan preparat histologis dan pengukuran pertumbuhan. Untuk asai enzim dibutuhkan sampel larva sebanyak 0,5 gr. Pengamatan enzim pencernaan dilakukan pada larva yang berumur 1, 2, 3, 5, 7, 10 dan 15 hari. Larva dipanen setelah megalami pemberokan selama 4 jam. Larva hasil pemanenan dibersihkan dari pakan alami dan kotoran yang terbawa, selanjutnya dilakukan analisis terhadap aktifitas enzim protease, lipase dan amilase.

Analis protease dilakukan dengan membuat campuran yang terdiri dari $0,5 \mathrm{ml}$

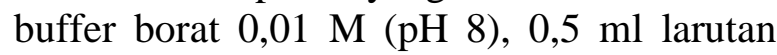
substrat kasein $1 \%$ dan $0,1 \mathrm{ml}$ larutan enzim dalam $\mathrm{CaCl}_{2}$. selanjutnya campuran tersebut diinkubasi pada suhu $37^{\circ} \mathrm{C}$ selama 10 menit. Kemudian ditambahkan $1 \mathrm{ml}$ larutan asam Trichloroacetic (TCA) $0,1 \quad \mathrm{M}$ untuk menghentikan reaksi yang sedang berlangsung dan diinkubasi lagi pada suhu 37 ${ }^{\circ} \mathrm{C}$ selama 10 menit, kemudian disentrifuse selama 10 menit dengan kecepatan 3000 rpm. Pada filtrat yang dihasilkan, ditambahkan 2,5 $\mathrm{ml} \mathrm{Na} \mathrm{CO}_{3}$ dan $0,75 \mathrm{ml}$ reagen Folin (1:2), kemudian diinkubasi kembali pada suhu 37 ${ }^{\circ} \mathrm{C}$ selama 20 menit. Selanjutnya dilakukan pengukuran menggunakan spetrofotometer pada panjang gelombang $578 \mathrm{~nm}$.

Analisis lipase dilakukan dengan mencampur 2 gr minyak kelapa sawit dengan $4 \mathrm{ml}$ buffer asetat $0,05 \mathrm{M} \mathrm{pH} \mathrm{5,6} \mathrm{dan} 1 \mathrm{ml}$ $\mathrm{CaCl}_{2} 1 \mathrm{M}$ serta $1 \mathrm{ml}$ enzim. Campuran tersebut diinkubasi pada plate stirer $30{ }^{\circ} \mathrm{C}$.
Setelah 1jam masa inkubasi, reaksi enzim diinaktifkan menggunakan aseton : etanol (1:1) sebanyak $10 \mathrm{ml}$ dan ditambahkan $2-3$ tetes indikator phenophtalin (pp) $1 \%$ dan dititrasi menggunakan $\mathrm{KOH} \mathrm{0,05} \mathrm{N.}$

Analisis amilase dilakukan dengan mencampur $1 \mathrm{ml}$ cairan enzim dan $1 \mathrm{ml}$ larutan pati $1 \%$ (dalam buffer sitrat $\mathrm{pH} 5,7$ ) dan diinkubasi pada suhu $20{ }^{\circ} \mathrm{C}$ selama 30 menit. Selanjutnya ditambahkan $2 \mathrm{ml}$ pereaksi dinitrosalicylic (DNS) untuk menginaktifkan rekasi yang sedang berjalan dan ditempatkan dalam air mendidih selama 5 menit. Selanjutnya diukur dengan spektrofotometer pada panjang gelombang $550 \mathrm{~nm}$.

\section{Pengamatan terhadap bukaan mulut dan saluran pencernaan}

Pengamatan lebar bukaan mulut larva dilakukan dengan mengukur panjang rahang dari sudut mulut hingga ujung tulang rahang bagian atas dan dihitung berdasarkan rumus berikut;

$$
\mathrm{bm}=\mathrm{ra} \times \sqrt{2}
$$

\footnotetext{
Keterangan:

bm : bukaan mulut maksimum larva (mm) ra : panjang rahang atas larva $(\mathrm{mm})$
}

Pengamatan saluran pencernaan dilakukan pada larva yang berumur 1, 2, 3, 5, 7, 10 dan 15 hari menggunakan metode preparat histologis. Pada umur yang sama juga dilakukan pengamatan terhadap isi saluran pencernaan larva menggunakan mikroskop.

Tabel 2. Substrat dan peubah yang digunakan dalam asai enzim pencernaan larva ikan patin, Pangasius hypophthalmus.

\begin{tabular}{llllll}
\hline \multicolumn{1}{c}{ Enzim } & \multicolumn{1}{c}{ Substrat } & Larutan Buffer & $\mathbf{p H}$ & ${ }^{\circ} \mathbf{C}$ & \multicolumn{1}{c}{ Pustaka } \\
\hline Protease & Kasein 2\% & Borat 0,01 M & 8,0 & 37 & Bergmeyer et al., 1983 \\
Lipase & Minyak kelapa & Asetat 0,05 M & 5,6 & 30 & Linfield et al., 1984 \\
Amilase & Larutan pati & Sitrat & 5,7 & 20 & Bernfield et al., 1955 \\
\hline
\end{tabular}


Pengamatan isi saluran pencernaan larva meliputi jenis dan jumlah pakan alami yang terdapat didalamnya. Jumlah cacing yang dihitung berdasarkan jumlah potongan yang ditemukan. Jumlah pakan alami larva dihitung setiap jenisnya menggunakan rumus sebagai berikut;

$$
\mathrm{J}_{\mathrm{p}}=\frac{\mathrm{J}_{\mathrm{x}}}{\mathrm{n}}
$$

Keterangan:

$$
\begin{array}{cl}
\mathrm{J}_{\mathrm{p}}: & \text { Jumlah satu jenis pakan alami } \\
& \text { (individu atau koloni/larva) } \\
\mathrm{J}_{\mathrm{x}}: & \begin{array}{l}
\text { Jumlah total satu jenis pakan alami } \\
\text { (individu atau koloni) }
\end{array} \\
\mathrm{n} \quad \text { : Jumlah sampel larva yang diamati }
\end{array}
$$
(ekor)

\section{Pertumbuhan panjang dan bobot larva}

Pertumbuhan panjang tubuh larva diamati dengan cara mengukur panjang tubuh total, dari ujung terminal mulut sampai ujung sirip ekor. Pengukuran panjang dilakukan setiap 2 hari dengan menggunakan rumus sebagai berikut;

$$
\mathrm{P}_{\mathrm{m}}=\mathrm{P}_{\mathrm{t}}-\mathrm{P}_{0} \quad \text { (Effendie, 1979) }
$$

Keterangan:

$$
\begin{aligned}
& \mathrm{P}_{\mathrm{m}}: \begin{array}{l}
\text { Pertumbuhan panjang mutlak larva } \\
(\mathrm{mm})
\end{array} \\
& \mathrm{P}_{\mathrm{t}}: \text { Panjang larva pada waktu ke-t }(\mathrm{mm}) \\
& \mathrm{P}_{0}: \text { Panjang larva pada waktu ke-0 }(\mathrm{mm})
\end{aligned}
$$

Pengamatan bobot tubuh larva dilakukan dengan cara menimbang larva sebanyak 10 ekor setiap 2 hari. Laju pertumbuhan bobot harian diukur berdasarkan rumus berikut;

$$
\alpha=\left[\sqrt[t]{\frac{W_{t}}{W_{0}}}-1\right] \times 100 \%
$$

$$
\text { (Huisman, 1976) }
$$

Keterangan;

$$
\begin{array}{ll}
\alpha & : \text { Laju pertumbuhan harian individu (\%) } \\
\mathrm{t} & : \text { Waktu/periode pengamatan (hari) } \\
\mathrm{W}_{\mathrm{t}}: & \text { Bobot rata-rata larva pada waktu ke- } \mathrm{t} \\
& (\mathrm{mg}) \\
\mathrm{W}_{0}: & \text { Bobot rata-rata larva pada waktu ke-0 } \\
& (\mathrm{mg})
\end{array}
$$

Selain itu juga dilakukan pengamatan terhadap tingkat kelangsungan hidup larva serta kualitas air pemeliharaan yang meliputi suhu, oksigen terlarut, karbon dioksida bebas, pH, amoniak, kesadahan dan alkalinitas air.

\section{HASIL DAN PEMBAHASAN}

\section{Enzim pencernaan larva}

Aktifitas enzim protease memiliki pola yang sama yaitu mengalami puncak pada umur 7 hari dengan nilai yang bervariasi antar perlakuan. Aktifitas enzim perlakuan II yang berkisar antara 0,021 - 0,568 $\mu \mathrm{Mol} /$ menit, relatif lebih tinggi dibandingkan dengan perlakuan lain. Perlakuan I berkisar antara 0,006 - 0,262 $\mu \mathrm{Mol} / \mathrm{menit}$, sedangkan perlakuan III hanya berkisar antara 0,014 $0,157 \mu \mathrm{Mol} /$ menit. Demikian pula dengan aktifitas enzim lipase yang memiliki pola hampir sama untuk masing-masing perlakuan yaitu mengalami puncak pada umur 5 hari. Aktifitas lipase perlakuan I berada pada kisaran $0,043-1,805 \mu \mathrm{Mol} /$ menit, perlakuan II antara $0,043-1,875$ $\mu \mathrm{Mol} / \mathrm{menit}$ dan perlakuan III antara $0,043-$ $1,855 \mu \mathrm{Mol} /$ menit. Pola aktifitas amilase pada ikan patin selama 15 hari pertama mengalami dua kali puncak yaitu pada umur 2 hari dan 7 hari. Pola tersebut relatif sama untuk masing-masing perlakuan dengan nilai yang bervariasi. Aktifitas tertinggi dicapai oleh perlakuan II dengan kisaran 1,965 $8,750 \mu \mathrm{Mol} /$ menit, sedangkan perlakuan I berkisar antara $1,550-8,400 \mu \mathrm{Mol} /$ menit dan Perlakuan III berkisar antara 0,550 $8,630 \mu \mathrm{Mol} /$ menit.

Aktifitas enzim protease sudah terdeteksi sejak larva baru berumur 1 hari. Hal ini diduga karena pada umur tersebut, saluran pencernaan larva sudah mulai berkembang dan terjadi proses metabolisme terhadap kuning telur yang terdapat pada larva. Kuning telur ikan mengandung asam amino dan lipid sehingga larva memperoleh energi dari hasil katabolisme asam amino dan fosfolipid tersebut. Aktifitas enzim protease menurun pada hari ke-3 akibat telah habisnya kuning telur dan adanya eksoenzim dari Artemia yang diberikan sehingga produksi enzim oleh larva cenderung menurun. 
Dengan semakin berkembangnya saluran pencernaan larva terbukti dapat meningkatkan aktifitas protease larva sehingga mencapai puncak pada umur 7 hari. Perkembangan saluran pencernaan larva ikan patin ditandai dengan meningkatnya luas permukaan usus (penambahan panjang dan lekukan bagian dalam usus) dan semakin meningkatnya konsumsi larva terhadap pakan dari luar. Dengan demikian, aktifitas protease tersebut merupakan respon saluran pencernaan terhadap peningkatan kualitas dan kuantitas pakan (Kawai dan Ikeda), 1973; Hofer dan Udin, 1985; Cousin at al., 1987). Aktifitas protease larva yang dipelihara dengan perlakuan II cenderung lebih tinggi dibandingkan dengan perlakuan lainnya. Hal ini disebabkan oleh larva yang mulai mencerna cacing yang tidak mengandung eksoenzim, sedangkan saluran pencernaannya belum siap untuk mencernanya yang ditandai dengan rendahnya tingkat kelangsungan hidup pada perlakuan II.

Aktifitas lipase pada larva ikan patin sudah terdeteksi sejak dini dan cenderung terus meningkat. Pada ikan betutu yang dipelihara pada cahaya normal maupun teduh, aktifitas lipase juga sudah terdeteksi sejak dini dan cenderung meningkat hingga umur 12 hari (Effendi, 1995). Tingginya aktifitas lipase saluran pencernaan larva pada awal hidupnya (saat larva belum makan), juga terjadi pada beberapa spesies antara lain $M$. rosenbergii yang diduga akibat adanya kelenjar pencernaan larva yang penuh dengan butir lipid embrionik (Kamarudin et al., 1994).

Sejak umur 2 hari, aktifitas lipase larva ikan patin terus meningkat hingga umur 5 hari. Peningkatan tersebut diduga akibat semakin berkembangnya saluran pencernaan larva, terutama semakin luasnya permukaan bagian dalam usus. Selain itu larva juga sudah dapat beradaptasi terhadap pakan terutama zooplankton yang ditandai dengan tingkat konsumsinya terhadap Artemia dan zooplankton tertinggi pada hari ke-5. Setelah umur 5 hari, aktifitas lipase cenderung menurun. Penurunan aktifitas lipase diduga disebabkan oleh adanya aktifitas enzim tersebut yang berasal dari pakan luarnya.
Selain itu juga desebabkan mulai tercapainya kesempurnaan saluran pencernaan larva.

Aktifitas amilase memiliki pola yang sama untuk semua perlakuan. Aktifitas amilase yang tinggi sudah terdeteksi sejak stadia awal larva yang menggambarkan respon terhadap tingginya konsumsi terhadap fitoplankton, terutama pada perlakuan I. Berdasarkan penelitian Gawlicka (2000), bahwa kontribusi aktifitas amilase dan Artemia terhadap total aktifitas enzim pencernaan lebih tinggi daripada aktifitas protease dan lipase. Artemia merupakan herbivor yang diperkirakan mempunyai aktifitas amilase tinggi untuk mencerna karbohidrat (Semain et al., dalam Gawlicka, 2000). Tingkat aktifitas amilase pada zoea beberapa krustasea (bersifat herbivor) lebih tinggi dibanding stadia lainnya (bersifat karnivor) (Kamarudin et al., 1994). Ini menunjukkan bahwa larva patin pada awal hidupnya cenderung bersifat herbivor seperti pada kebanyakan spesies ikan lainnya. Tingkat aktifitas enzim amilase lebih tinggi dibanding enzim protease dan lipase pada semua perlakuan.

Aktifitas amilase menurun pada hari ke-5 dan meningkat lagi pada hari ke-7 yang kemudian cenderung menurun sampai akhir penelitian. Menurunnya aktifitas amilase tersebut diduga disebabkan oleh meningkatnya konsumsi larva terhadap zooplankton yang menunjukkan telah bergesernya sifat pemangsaan larva dari herbivora ke karnivora.

Meningkatnya aktifitas ketiga enzim tersebut terjadi pada awal stadia larva hingga umur 7 hari. Hal ini terjadi karena kontribusi pakan serta enzim endogenous sudah berkembang sejalan dengan perkembangan morfologi saluran pencernaan. Peningkatan aktifitas enzim ini ditandai dengan menurunnya tingkat kelangsungan hidup larva. Fase tersebut merupakan fase kritis yaitu terjadi transisi sumber energi dari kuning telur (endogen) ke pakan dari luar (eksogen). Larva yang saluran pencernaannya masih sederhana harus memproduksi enzim pencernaan secara cepat agar mampu mencerna pakan dari luar. Larva yang tidak mampu mencerna pakannya akan mati sehingga menurunkan tingkat 
kelangsungan hidupnya. Tingkat kelangsungan hidup yang rendah juga disebablan oleh kanibalisme antar larva karena pada stadia awal, ikan patin bersifat kanibal.

\section{Saluran pencernaan}

Larva umur 1 hari memmiliki saluran pencernaan yang masih sederhana, kemudian terus berkembang sejalan dengan bertambahnya umur larva. Saluran pencernaan semakin sempurna dengan adanya lekukan usus yang terlihat jelas. Hamper tidak ada perbedaan perkembangan usus larva antara masing-masing perlakuan. Pengamatan terhadap isi saluran pencernaan larva ikan patin menunjukkan keberadaan Artemia, cacing dan plankton yang terkonsumsi. Jumlah Artemia yang dikonsumsi larva cenderung meningkat sampai umur 5 hari. Penurunan ini terjadi karena larva sudah dapat mencerna atau mengkonsumsi cacing lebih banyak yang ditandai dengan meningkatnya jumlah cacing yang diperoleh dari saluran pencernaannya sampai umur 15 hari. Cacing mulai ditemukan dalam saluran pencernaan larva pada umur 3 hari (perlakuan III), umur 5 hari (perlakuan II) dan umur 7 hari (perlakuan I).

Fitoplankton selalu ditemukan dalam saluran pencernaan larva masing-masing pada perlakuan dan jumlahnya cenderung meningkat sampai akhir penelitian. Sedangka konsumsi larva terhadap zooplankton terbanyak terjadi pada larva umur 5 hari dan 10 hari dan cenderung menurun sampai umur 15 hari.

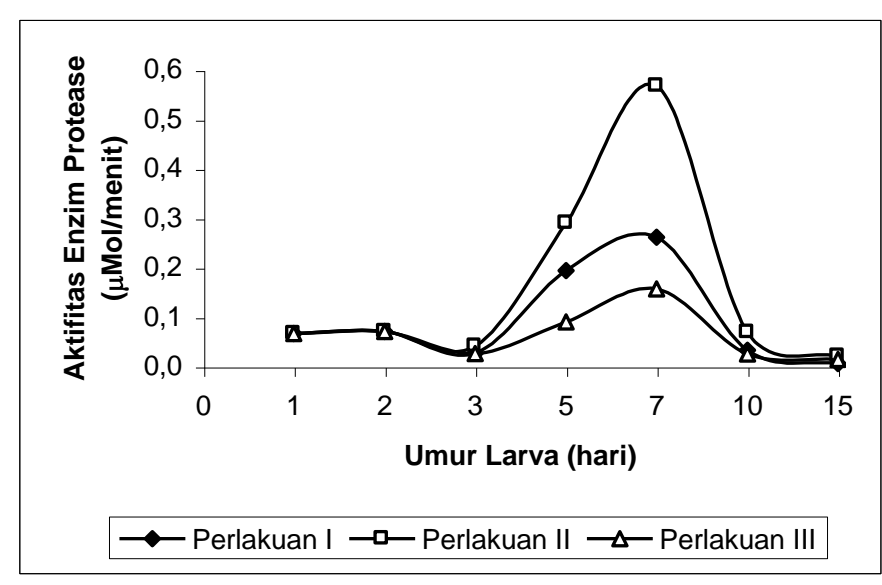

Gambar 1. Aktifitas enzim protease larva ikan patin, Pangasius hypophthalmus, yang dipelihara dengan jadwal pemberian pakan berbeda

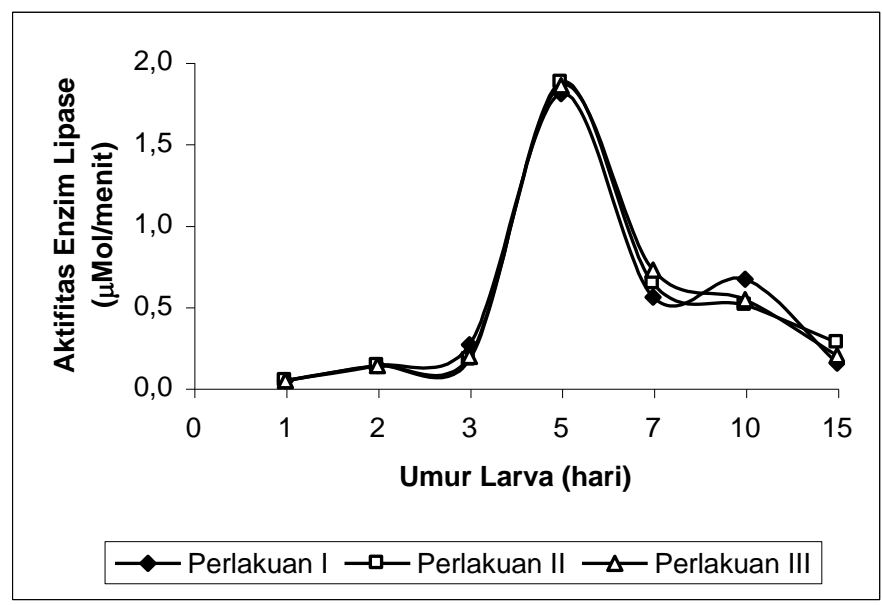

Gambar 2. Aktifitas enzim lipase larva ikan patin, Pangasius hypophthalmus yang dipelihara dengan jadwal pemberian pakan berbeda 


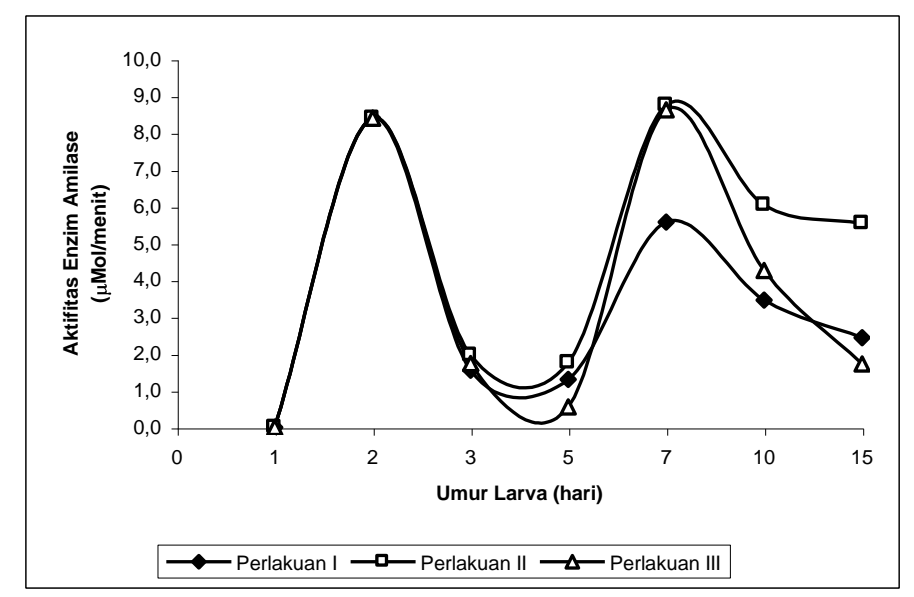

Gambar 3. Aktifitas enzim amilase larva ikan patin, Pangasius hypophthalmus yang dipelihara dengan jadwal pemberian pakan berbeda

Tabel 3. Kualitas air selama pemeliharaan larva ikan patin, Pangasius hypophthalmus

\begin{tabular}{lccc}
\hline \multicolumn{1}{c}{ Parameter } & Perlakuan I & Perlakuan II & Perlakuan III \\
\hline Oksigen terlarut (ppm) & $7,44-8,25$ & $6,93-7,66$ & $7,01-7,66$ \\
Karbon dioksida (ppm) & $5,94-9,90$ & $5,94-10,89$ & $5,94-7,92$ \\
pH & $7,50-8,52$ & $8,05-8,27$ & $7,83-8,29$ \\
Amonia (ppm) & $0,008-0,029$ & $0,008-0,052$ & $0,008-0,031$ \\
Alkalinitas (ppm) & $16,92-23,89$ & $16,92-25,88$ & $16,92-26,88$ \\
Kesadahan (ppm) & $15,05-22,57$ & $15,05-22,57$ & $15,05-22,57$ \\
\hline
\end{tabular}

\section{Pertumbuhan larva}

Pertumbuhan panjang larva meningkat sejalan dengan bertambahnya umur dengan nilai yang tidak berbeda nyata untuk masingmasing perlakuan. Hal tersebut juga terjadi pada pertumbuhan bobot larva sampai umur 15 hari. Pertumbuhan panjang dan bobot larva meningkat secara cepat sejak hari ke-7 yang berhubungan dengan perkembangan saluran pencernaannya. Pertumbuhan panjang mutlak dan laju pertumbuhan bobot harian larva memiliki nilai yang relative sama pada setiap perlakuan. Namun tingkat kelangsungan hidup larva pada perlakuan I relative lebih tinggi dan tidak sama pada masing-masing perlakuan. Hal ini membuktikan bahwa larva ikan patin belum siap sepenuhnya untuk menerima pakan berupa cacing sutera pada stadia awal. Media pemeliharaan yang digunakan selama penelitian juga menunjukkan kelayakan sehingga tidak mempengaruhi tingkat kelangsungan hidupnya. Kisaran suhu selama pemeliharaan tersaji pada table 3 .

\section{KESIMPULAN}

Aktifitas enzim protease pada larva ikan patin, Pangasius hypophthalmus memiliki pola yang sama untuk semua jadwal pemberian pakan. Aktifitas enzim cenderung meningkat sampai larva berumur 7 hari, selanjutnya terus menurun sampai larva berumur 15 hari. Aktifitas tertinggi dicapai oleh larva yang diberi pakan Artemia mulai umur 2 hari sampai 8 hari. Aktifitas lipase memiliki pola yang sama untuk semua perlakuan yaitu cenderung naik sampai larva berumur 5 hari kemudian turun sampai umur 15 hari. Sedangkan pola aktifitas enzim amilase cenderung menurun sampai larva berumur 5 hari, naik pada umur 7 hari dan turun kembali sampai akhir penelitian. 
Kelangsungan hidup ikan selama penelitian berbeda-beda untuk setiap perlakuan dengan nilai tertinggi dicapai oleh larva yang diberi pakan Artemia sampai berumur 8 hari. Larva ikan patin belum siap sepenuhnya untuk menerima pakan berupa cacing sutera sejak stadia awalnya.

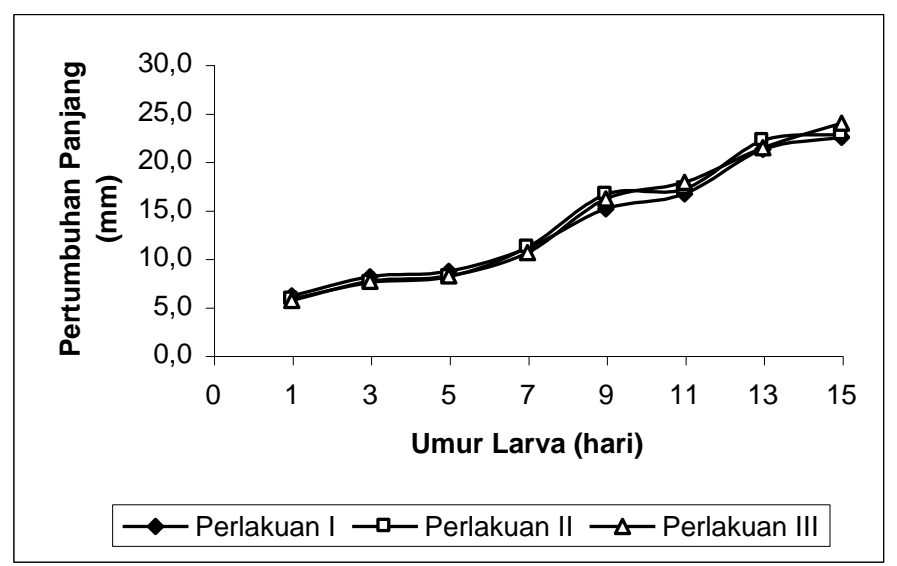

Gambar 4. Pertumbuhan panjang ikan patin, Pangasius hypophthalmus yang dipelihara dengan jadwal pemberian pakan berbeda

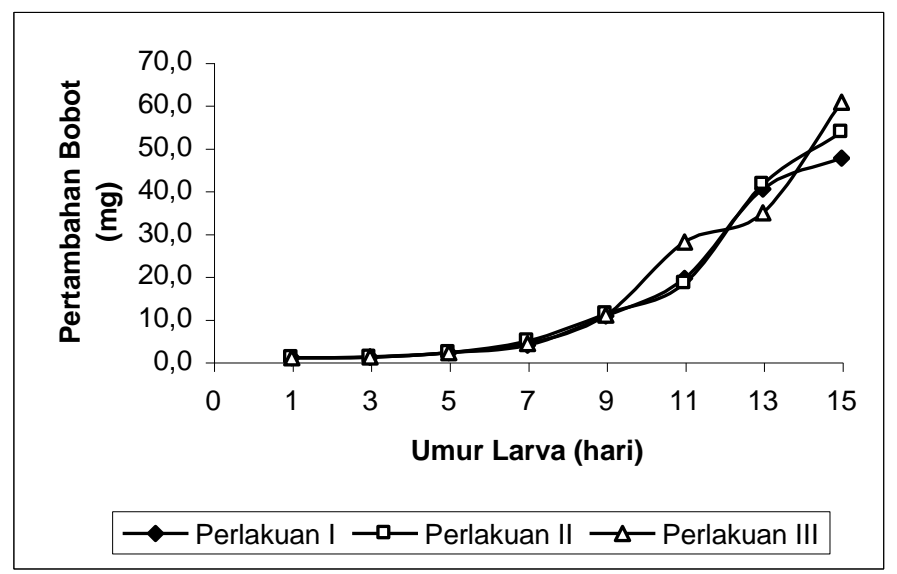

Gambar 4. Pertambahan bobot ikan patin, Pangasius hypophthalmus yang dipelihara dengan jadwal pemberian pakan berbeda

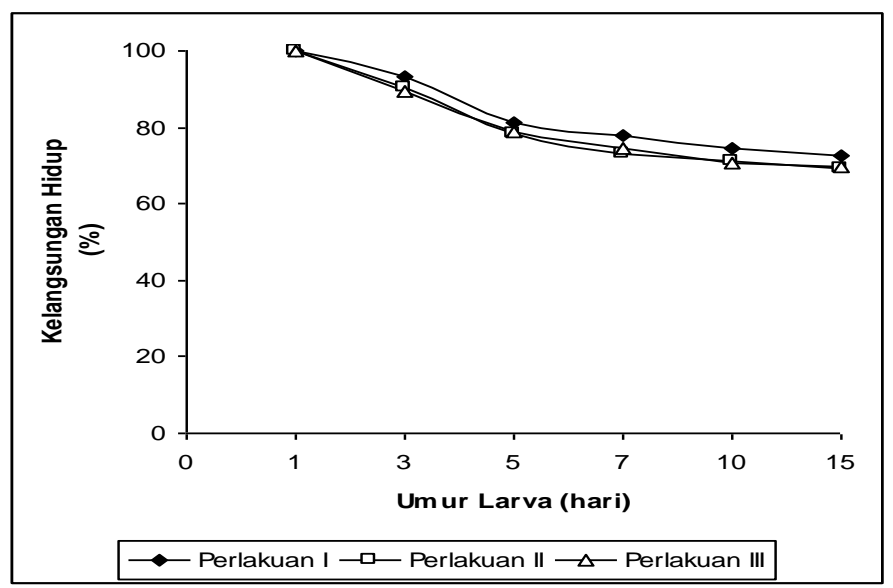

Gambar 4. Tingkat Kelangsungan hidup Ikan Patin, Pangasius hypophthalmus yang Dipelihara dengan Jadwal Pemberian Pakan Berbeda 


\section{DAFTAR PUSTAKA}

Bergmeyer, H. U., M. Grossl H. E. Walter. 1974. Reagent for Enzymatic Analysis, p:274 - 275. In H. U. Bergmeyer (ed), Methods of Enzymatic Analysis, $3^{\text {rd }}$ Edition, Volume II. Verlag Chemie, Weinhem.

Bernfield, P. 1955. Amylase A and B, p: 149 - 157. In P. Colowick and N. O. Kaplan (Eds), Methods in Enzymology, Vol. I. Academic Press, New York.

Buddington, R. K. 1985. Digestive Secretion of Lake Sturgeon, Acipenceser fulvescens, During Early Development. J. Fish Biol., 26: 715 723.

Cousin, J. C. B., F. Baudin-Laurencin \& J. Gabaudan. 1987. Ontogeny of Enzymatic Activities in Fed and Fasting Turbot, Scophthalmus maximus L. J. Fish Biol., 30: 15 - 33.

Effendi, I. 1995. Perkembangan Enzim Pencernaan Larva Ikan Betutu, Oxyeletris marmorata (BLKR) yang Dipelihara pada Cahaya Normal dan Teduh. Tesis Program Pascasarjana IPB, Bogor.

Effendie, M. I. 1979. Biologi Perikanan. Yayasan Pustaka Nusatama, Yogyakarta. 162 p.

Gawlicka, A., P. Brigitte, M. H. Horn, R. Neil, O. Ingergjerd \& J. T. Ole. 2000. Activity of Digestive Enzyme in Yolk-sac Larvae of Atlantic Halibut (Hippoglossus hippoglossus):
Indication of Readiness for First Feeding. Aquaculture, 184: 303 314.

Hernowo. 2001. Pembenihan Patin Skala Kecil dan Besar, Solusi Permasalahan. Swadaya, Jakarta. 66 hal.

Huisman, E. A. 1976. Food Conversion Efficiencies at Mainenance and Production Levels for Carp, Cyprinus carpio L., Rainbow trout, Onchoryncus mykis R. Aquaculture, 9(3): 259-273.

Kawai, S. \& Ikeda, S. 1973. Studies on The Digestive Enzymes of Fishes III. Development of The Digestive Enzymes of Rainbow Trout After Hatching and The Effect of Dietary Change on The Activities of Digestive Enzymes in The Juvenile Stage. Bulletin of Japanese Society of Scientific Fisheries, 39: 819 - 823.

Kamarudin, M. S., D. A. Jones, L. Le Vay \& A. Z. Abidin 1994. Ontogenetic Change in Digestive Enzyme Activity During Larval Development of Macrobrachium rosenbergii. Aquaculture, 123: 323 - 333.

Linfield, W. M., R. A. Barangkas, L. Sivieri, S. Serosta \& R. W. Stevenson. 1984. Enzymatic fat and Synthesis. JAOCS, 18(2): $78-87$.

Stroband, H. J. W. and K. R. Dabrowski. 1979. Morphological and Pdysiological Aspects of The Digestive System and Feeding in Freshwater Fish Larvae. CNERNA, Paris. $\quad$ P: $356 \quad-376$. 